\title{
\$h\$-Vectors of Generalized Associahedra and Noncrossing Partitions
}

Colum Watt

Technological University Dublin, colum.watt@TUDublin.ie

Thomas Brady

Dublin City University, thomas.brady@dcu.ie

Christos A. Athanasiadis

University of Athens, caath@math.uoa.gr

See next page for additional authors

Follow this and additional works at: https://arrow.tudublin.ie/scschmatart

Part of the Mathematics Commons

\section{Recommended Citation}

Watt, C., Brady, T. \& Athanasiadis, C. (2007). \$h\$-Vectors of Generalized Associahedra and Noncrossing Partitions. International Mathematical Research Notices, vol. 1, no. 29, article ID 69705. doi:10.1155/ IMRN/2006/69705

This Article is brought to you for free and open access by the School of Mathematics at ARROW@TU Dublin. It has been accepted for inclusion in Articles by an authorized administrator of ARROW@TU Dublin. For more information, please contact arrow.admin@tudublin.ie, aisling.coyne@tudublin.ie,gerard.connolly@tudublin.ie.

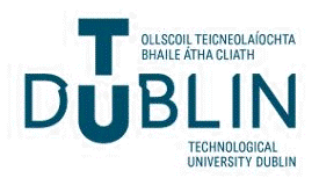




\section{Authors}

Colum Watt, Thomas Brady, Christos A. Athanasiadis, and Jon McCammond 


\title{
$h$-VECTORS OF GENERALIZED ASSOCIAHEDRA AND NONCROSSING PARTITIONS
}

\author{
CHRISTOS A. ATHANASIADIS, THOMAS BRADY, JON MCCAMMOND, \\ AND COLUM WATT
}

\begin{abstract}
A uniform proof is given that the entries of the $h$ vector of the cluster complex $\Delta(\Phi)$, associated by S. Fomin and A. Zelevinsky to a finite root system $\Phi$, count elements of the lattice $\mathbf{L}$ of noncrossing partitions of corresponding type by rank. Similar interpretations for the $h$-vector of the positive part of $\Delta(\Phi)$ are provided. The proof utilizes the appearance of the complex $\Delta(\Phi)$ in the context of the lattice $\mathbf{L}$ in recent work of two of the authors, as well as an explicit shelling of $\Delta(\Phi)$.
\end{abstract}

This article has appeared in International Mathematical Research Notices, (2007), article ID 69705.

Department of Mathematics (Division of Algebra-Geometry), UniverSity of Athens, Panepistimioupolis, 15784 Athens, Greece

E-mail address: caath@math.uoa.gr

School of Mathematical Sciences, Dublin City University, Glasnevin, Dublin 9, IRELAND

E-mail address: tom.brady@dcu.ie

Mathematics Department, University of California, Santa Barbara, Santa Barbara, CA 93106, U.S.A

E-mail address: jon.mccammond@math.ucsb.edu

School of Mathematical Sciences, Dublin Institute of Technology, Dublin 8, IRELAND

E-mail address: colum.watt@dit.ie

Date: June 20, 2006, Final Version 26/6/06.

2000 Mathematics Subject Classification. Primary 20F55; Secondary 05E99. 